\title{
Plants of the Cerrado with antimicrobial effects against Staphylococcus spp. and Escherichia coli from cattle
}

Izabella Carolina de O. Ribeiro', Emanuelly Gomes A. Mariano', Roberta T. Careli', Franciellen Morais-Costa', Felipe M. de Sant'Anna ${ }^{2}$, Maximiliano S. Pinto ${ }^{1}$, Marcelo R. de Souza ${ }^{2}$ and Eduardo R. Duarte ${ }^{1,3^{*}}$

\begin{abstract}
Background: Both diarrhea in calves and mastitis in cows limit cattle production. The bacteria involved in these diseases have shown multi-resistance to antimicrobials, however plant metabolites therefore can provide an alternative method of control. This study selected and characterized Cerrado plant extracts showing inhibitory effects against Escherichia coli and Staphylococcus spp. from cattle. Thirteen leaf extracts were initially screened and diameters of inhibition zones produced against the pathogens were recorded using an agar disk diffusion method. Total condensed tannin contents were determined and antibacterial activities were analyzed after tannin removal from the five selected extracts. The minimum inhibitory concentrations (MIC) and minimum bactericidal concentrations (MBC) were evaluated by macro-dilution antimicrobial susceptibility tests, and the extracts were characterized by high performance liquid chromatography.
\end{abstract}

Results: Inter- and intra-specific bacterial variations in the susceptibility to the extracts were detected. The aqueous extract (AE) from Caryocar brasiliense Cambess. leaves produced larger inhibition zones against $E$. coli strains than did other selected extracts. However, the AE from Schinopsis brasiliensis was the most effective against Staphylococcus spp. strains $(P<0.001)$. The MIC of ethanolic extracts (EE) from C. brasiliense $(0.27 \mathrm{mg} / \mathrm{mL})$ and S. brasiliensis $(0.17 \mathrm{mg} / \mathrm{mL})$ were lower than those of other extracts. The MIC and MBC of the Annona crassiflora EE were $6.24 \mathrm{mg} / \mathrm{mL}$ for all bacteria. Flavonoids were the main metabolites detected in the A. crassiflora EE as well as in the AE and EE from C. brasiliense, while tannins were the main metabolites in the S. brasiliensis leaf extracts.

Conclusion: The AE from C. brasiliense was more effective against Gram-negative bacteria, while the AE from S. brasiliensis was more effective against Gram-positive bacteria. A. crassiflora EE and S. brasiliensis extracts are potent bactericide. After removal of the tannins, no antimicrobial effects were observed, indicating that these metabolites are the main active antibacterial components.

Keywords: Antibacterial, Brazilian savannah, Colibacillosis, Mastitis, Medicinal plants, Staphylococcus Aureus, Staphylococcus haemolyticus

\section{Background}

Diseases must be prevented or controlled in order to achieve a sustainable and viable production of ruminants. Diarrhea is the most common pathology in young calves

\footnotetext{
* Correspondence: duartevet@hotmail.com

${ }^{1}$ Instituto de Ciências Agrárias, Universidade Federal de Minas Gerais, Avenida Universitária, 1000, Bairro Universitário, Montes Claros, Minas Gerais CEP 39401-790, Brazil

${ }^{3}$ Instituto de Ciências Agrárias, Universidade Federal de Minas Gerais, Av Universitária 1000, Bairro Universitario, Montes Claros, MG 39400-006, Brazil Full list of author information is available at the end of the article
}

and Escherichia coli represents one of its main etiological agents [1, 2]. Mastitis, caused by the Staphylococcus spp., is the most important disorder in cows, and leads to reduced milk production and increased production costs [3, 4]. These bacteria have shown multi-resistance to antimicrobials in different continents and present a public health risk $[2,5-7]$.

Plant metabolites are considered alternative control agents for the reduction of resistant microorganisms and antimicrobial residues in foods of animal origin [5-7]. 
Scientific literature has frequently reported the inhibitory action of certain plant extracts against bacteria in humans $[7,8]$. However, few studies have showed effective plant extracts inhibiting microorganisms from ruminants or other animals. Extracts from Solanum paniculatum L. (Jurubeba) and Punica granatum L. (Romã) display antibacterial effects against microorganisms that cause bovine mastitis [9], and Rhodomyrtus tomentosa L. (rose myrtle) leaf extract shows potent antibacterial activity against Staphylococcus aureus in milk [10]. Tannins are the main antimicrobial metabolites in vegetal extracts, and also inhibit enzymes and alter metabolism via membrane or cell wall interactions [11].

The Cerrado, a type of savannah present in South America, is native to more than 10,000 plant species that contain natural products for phytotherapy [12]. With regards to alternative antibacterial agents, four medicinal plants from the Brazilian Cerrado have been shown to inhibit the growth of S. aureus [13], and the leaf extract from Schinopsis brasiliensis Engl. is effective against multidrug-resistant $S$. aureus [14].

However, the antimicrobial activity of plant species from the Brazilian Cerrado against animal pathogens has not been fully explored. Extracts from these plants that show antibacterial effects could favor the alternative controls, thereby reducing pathogen multi-resistance. In organic animal production systems, the use of these extracts would enable the production of foods free from antimicrobial residues, thus increasing the value of these animal products.

In this study, plant species commonly found in the Cerrado were selected and their antimicrobial activities were evaluated against isolates of E. coli and Staphylococcus spp. from cattle. To identify the main antibacterial components, these extracts were characterized by high performance liquid chromatography (HPLC), and inhibitory activity was analyzed after tannin removal.

\section{Methods}

\section{Microorganisms}

The antibacterial effects of the plant extracts were evaluated against three Staphylococcus isolates (S178, S135, and S182) from cows with mastitis. These bacteria were isolated and cultured on mannitol salt agar, and evaluated based on colony characteristics, Gram staining, catalase reaction, and coagulase test. We also assessed the inhibitory effects of the extracts on two E. coli isolates (E2 and E3) from the feces of dairy calves with diarrhea. These were isolated and cultured on MacConkey agar and colony characteristics, Gram staining, and catalase reactions were evaluated. These animals were raised on an experimental farm in northern Minas Gerais, Brazil. In addition, the human clinical isolates $S$. aureus ATCC 25923 and E. coli ATCC 25922 were included as reference strains. All bacteria were cultured in Brain Heart Infusion (BHI) broth, and subsamples were stored at $-80^{\circ} \mathrm{C}$ after glycerol inclusion (1:1).

DNA from these bovine isolates was extracted and amplified as described by Chapaval et al. [15]. DNA samples were amplified via polymerase chain reaction (PCR) using primers 27F (5'-AGAGTTTGATCCTGGC TCAG-3') and 1492R (5'-GGTTACCTTGTTACGA CTT-3'), as described by Lane [16]. $16 \mathrm{~S}$ ribosomal RNA (rRNA) was sequenced following the method described by Sanger [17], using the automatic sequencer MegaBACE $^{\circ} 1000$ (GE Life Sciences, USA), according to Reysenbach et al. [18]. 16S rRNA gene sequencing was verified using the SeqScanner Software ${ }^{\circ}$ v1.0 (Applied Biosystems, USA), and the results were compared online by BLAST (database from NCBI - https://blast.ncbi.nlm. nih.gov/Blast.cgi). The bacteria species were identified with a similarity level of at least $99 \%$.

\section{Antibacterial susceptibility}

The procedure for the agar disk diffusion method was performed in triplicate, according to recommendations by the National Committee for Clinical Laboratory Standards (NCCLS) [19]. For Staphylococcus strains, the following antimicrobial discs were added onto the medium surface: chloramphenicol, $30 \mu \mathrm{g}$; erythromycin, $15 \mu \mathrm{g}$; vancomycin, $30 \mu \mathrm{g}$; oxacillin, $1 \mu \mathrm{g}$; gentamicin, $10 \mu \mathrm{g}$; tetracycline, $30 \mu \mathrm{g}$; clindamycin, $2 \mu \mathrm{g}$; and penicillin, $10 \mu \mathrm{g}$. For E. coli strains, the following were used: chloramphenicol, $30 \mu \mathrm{g}$; ampicillin, $10 \mu \mathrm{g}$; gentamicin, $10 \mu \mathrm{g}$; ciprofloxacin, $5 \mu \mathrm{g}$; tetracycline, $30 \mu \mathrm{g}$; and norfloxacin, $10 \mu \mathrm{g}$, as described by the NCCLS [19]. For quality control purposes, the strains ATCC 25923 and ATCC 25922 were used. All plates were incubated at $35{ }^{\circ} \mathrm{C}$ for $24 \mathrm{~h}$, and inhibition zones $(\mathrm{mm})$ were measured and the bacteria were classified as resistant or sensitive according to the NCCLS guidelines [19].

\section{Plant extracts}

Plant leaves were collected from April to June at the Institute of Agricultural Sciences, UFMG, in Montes Claros, Minas Gerais, Brazil. This region is located at latitude $16^{\circ} 51^{\prime}$ and longitude $44^{\circ} 55^{\prime}$, and the climate is tropical and humid with dry summers (A) according to Köppen classification [20].

Vegetal materials were collected from Caryocar brasiliense Camb. (Caryocaraceae), Annona crassiflora Mart. (Annonaceae), S. brasiliensis Engl. (Anacardiaceae), Piptadenia viridiflora (Kunth) Benth. (Fabaceae), Serjania lethalis A.St.-Hil. (Sapindaceae), Casearia sylvestris (Flacourtiaceae), and Ximenia americanaL. (Olacaceae). Plant samples were deposited in the Montes Claros Herbarium of Universidade Estadual de Montes Claros, 
as voucher specimens $338,1492,377,2283,2249,3008$, and 211, respectively.

The leaves were carefully inspected, and those with gross lesions or damage were discarded. Selected leaves were dehydrated under forced air circulation (TE 394/4, Tecnal Equipamentos Científicos Tecnal, Piracicaba, SP, Brazil) at $38^{\circ} \mathrm{C}$ for $72 \mathrm{~h}$, crushed in a blender, and stored inside paper bags in the dark at $-4{ }^{\circ} \mathrm{C}[11,21]$.

Aqueous extracts (AEs) were produced by placing the ground dried leaves in a distilled water bath at $40{ }^{\circ} \mathrm{C}$ for $60 \mathrm{~min}$. Ethanolic extracts (EEs) were obtained from macerated dried leaves held in absolute ethanol in amber-colored glass containers in the dark for seven days. Extracts were filtered through a gauze funnel and subsequently evaporated at $40{ }^{\circ} \mathrm{C}$ for $48 \mathrm{~h}$ under forced air circulation until completely dry and stored at $4{ }^{\circ} \mathrm{C}$ until use [11]. In this study, both EEs and AEs were completely soluble in distilled water and did not require any other solvents for antimicrobial analysis.

Subsamples of extracts were subjected to tannin extraction according to the method described by Nyman et al. [22]. Extracts were dissolved in water $(1 \mathrm{~g}$ per $20 \mathrm{~mL})$ at $90{ }^{\circ} \mathrm{C}$ and cooled to room temperature. After reaching a temperature of $30{ }^{\circ} \mathrm{C}, 0.2 \mu \mathrm{L} 10 \% \mathrm{NaCl}$ was added, and $1 \mathrm{~mL}$ of this solution was combined with $4 \mathrm{~mL} 1 \%$ gelatin solution before centrifuging at $1800 \times \mathrm{g}$ for $6 \mathrm{~min}$. Supernatants were used to assess the effects of tannin-free extracts.

\section{Characterization of extracts}

A Waters Alliance 2695 HPLC system comprising a quaternary pump, auto-sampler, photodiode array detector (DAD) 2996, and Waters Empower Pro data handling system (Waters Corporation, Milford, Connecticut, USA) were used for extract characterization. Analyses were performed on a LiChrospher 100 RP-18 column $(250 \times 4 \mathrm{~mm}, 5 \mathrm{~mm}$; Merck, Darmstadt, Germany) combined with a LiChrospher 100 RP-18 guard column (4x $4 \mathrm{~mm}, 5 \mathrm{~mm}$; Merck) at $40{ }^{\circ} \mathrm{C}$. Water (A) and acetonitrile (B) were used as eluents, both containing $0.1 \%(\mathrm{v} /$ v) $\mathrm{H}_{3} \mathrm{PO}_{4}$ at a flow rate of $1.0 \mathrm{~mL} / \mathrm{min}$ as follows: $0 \mathrm{~min}$, $95 \% \mathrm{~A}$ and $5 \% \mathrm{~B} ; 60 \mathrm{~min}, 5 \% \mathrm{~A}, 95 \% \mathrm{~B}$, followed by $10 \mathrm{~min}$ isocratic elution. Solvents used were of HPLC grade (Merck, Germany) and were degassed by sonication before use. Chromatograms were obtained at $210 \mathrm{~nm}$, and the UV spectra were recorded online from 190 to $400 \mathrm{~nm}$.

The dried crude extracts were dissolved in methanol (HPLC-grade), ultrapure water, or hydroethanolic solutions according to their solubility, to concentrations of $10 \mathrm{mg} / \mathrm{mL}$. After centrifugation at $8400 \times \mathrm{g}$ for $10 \mathrm{~min}, 10 \mathrm{~mL}$ sample were automatically injected into the apparatus.
The total condensed tannin (proanthocyanidins) content of the extracts was determined by measuring the absorbance of cyanidin chloride resulting from acidcatalyzed solvolysis with $\mathrm{n}-\mathrm{BuOH} / \mathrm{HCl} 12 \mathrm{M}$ (95:5) at $540 \mathrm{~nm}$, according to the method described by Hiermann et al. [23]. Each sample was analyzed in triplicate and the total condensed tannin content, expressed as cyanidin chloride, was calculated using the following formula:

Condensed tannins \%= Absorbance (sample) $-\mathrm{Ab}$ sorbance (blank) $\times 4.155 /$ sample weight $(\mathrm{g})$.

\section{Selection of plant extracts with inhibitory effects}

Seven ethanolic and six aqueous extracts were diluted with distilled water at $0.1 \mathrm{~g}$ extract $/ \mathrm{mL}$ and vortexed for $3 \mathrm{~min}$. Extracts were used immediately after this preparation. Antibacterial activity was determined using the agar disk diffusion method [19, 24].

A loopful of bacteria was inoculated onto BHI agar under sterile conditions, and incubated at $37{ }^{\circ} \mathrm{C}$ for $24 \mathrm{~h}$. Turbidity equivalent to a $0.5 \mathrm{McF}$ arland standard was used as a reference to adjust for approximately $10^{8}$ colony-forming units $(\mathrm{CFU}) / \mathrm{mL}$. One hundred microliters of freshly prepared inoculum suspension were spread on Mueller-Hinton agar using sterile swabs [19]. Eight microliters of extract solution was added to 6-mm paper filter disks, allocated onto the surface of the seeded plates, and incubated at $35^{\circ} \mathrm{C}$ for $24 \mathrm{~h}$. Inhibition zones were then measured using a digital caliper [8]. In this screening assay, all procedures were performed in duplicate.

Based on the largest zones of inhibition and the broadest spectrum of action, five extracts were selected, both with and without tannins. These extracts were filtered through a $0.2-\mu \mathrm{m}$ Millipore membrane and aliquots were then submitted to dry matter $(\mathrm{dm})$ determination in an oven at $105{ }^{\circ} \mathrm{C}$, in order to standardize them at $1.58 \mathrm{mg} \mathrm{dm} / \mathrm{mL}$. Paper filter disks with sterile saline solution (without extract) and discs containing the extracts incubated without bacteria were used as controls [8, 24]. The experiment was designed in a factorial arrangement (5 extracts $\times 7$ bacterial strains) and all procedures were performed in triplicate. The inhibition zone averages were compared by the analysis of variance using ScottKnott's test at the 5\% significance level, using the System for Statistical Analysis software (SAEG 9.1).

\section{Minimum inhibitory concentration (MIC) and minimum bactericidal concentration (MBC)}

After filtration of the extracts, we determined the MIC necessary to inhibit the growth of the microorganism by macro-dilution in Mueller-Hinton broth, as described by the NCCLS [25]. 
Using a 1:2 dilution with an equal volume of medium, the final concentrations $(6.24-0.01 \mathrm{mg} / \mathrm{mL})$ were evaluated. However, for MBC determinations of the C. brasiliensis extracts were also evaluated concentrations up to $40 \mathrm{mg} / \mathrm{mL}$. Extract solutions were therefore prepared at double the final concentration [25]. Completing at final volume of $5 \mathrm{~mL}, 120 \mu \mathrm{L}$ of bacteria inoculum prepared as reported above were added together with $2.48 \mathrm{~mL}$ Mueller Hinto broth and $2.5 \mathrm{~mL}$ of extract solution.

For the controls, we used growth control tubes containing broth without extract for each bacterium tested, tubes without bacteria containing broth alone or added of extracts. All tubes were incubated at $35^{\circ} \mathrm{C}$ for $24 \mathrm{~h}$ in a thermo-shaker incubator (Novatécnica, São Paulo, SP, Brazil) to ensure homogenization. After this period, bacterial growth was assessed using $125 \mu \mathrm{L} 0.5 \%$ triphenyl tetrazolium chloride (TTC) solution, which indicates cellular multiplication through the development of a reddish color in the presence of viable cells, thus enabling MIC determination [26].

Subsequently, the MBC was determined, which represents the lowest concentration of the extract necessary to achieve complete suppression of bacterial growth. One hundred-microliter aliquots from the tubes used for the MIC assay and the control tubes without extracts were inoculated on Mueller-Hinton agar and incubated at $37{ }^{\circ} \mathrm{C}$ for $24 \mathrm{~h}$. The absence of bacterial growth on the agar plate was evaluated to determine $\mathrm{MBC}$, and the experiment was carried out in triplicate.

\section{Results}

\section{Characterization of bacterial isolates}

Using molecular analysis, we successfully identified isolate S178 as S. aureus and isolates S135 and S182 as S. haemolyticus (99.9\% similarity). Strains E2 and E3 were identified as E. coli, as shown in Table 1.

Isolate S178 (S. aureus) was resistant to erythromycin, clindamycin, oxacillin, penicillin, tetracycline, and vancomycin. However, S. haemolyticus isolates were sensitive to all antimicrobials tested in grampositive strains. All E. coli strains were resistant to tetracycline, while isolate E3 was also resistant to ampicillin and gentamicin (Table 2).
Table 2 Antimicrobial sensitivity profiles for Staphylococcus aureus, Staphylococcus haemolyticus, and Escherichia coli isolates from cattle and standard strains

\begin{tabular}{llllllll}
\hline & \multicolumn{2}{l}{ S. haemolyticus } & \multicolumn{2}{l}{ S. aureus } & \multicolumn{2}{l}{ E. coli } \\
\hline Antibacterial & S135 & S182 & S178 & ATCC & E2 & E3 & ATCC \\
Chloramphenicol & S & S & S & S & S & S & S \\
Erythromycin & S & S & R & S & - & - & - \\
Ampicillin & - & - & - & - & S & I & S \\
Vancomycin & S & S & R & R & - & - & - \\
Oxacillin & S & S & R & R & - & - & - \\
Gentamicin & S & S & S & S & S & I & I \\
Ciprofloxacin & - & - & - & - & S & S & S \\
Tetracycline & S & S & R & S & R & I & R \\
Clindamycin & S & S & R & R & - & - & - \\
Penicillin & S & S & R & R & - & - & - \\
Norfloxacin & - & - & - & - & S & S & S
\end{tabular}

chloramphenicol $30 \mu \mathrm{g}$, erythromycin $15 \mu \mathrm{g}$, ampicillin $10 \mu \mathrm{g}$, vancomycin $30 \mu \mathrm{g}$, oxacillin $1 \mu \mathrm{g}$, gentamicin $10 \mu \mathrm{g}$, ciprofloxacin $5 \mu \mathrm{g}$, tetracycline $30 \mu \mathrm{g}$, clindamycin $2 \mu \mathrm{g}$, penicillin $10 \mu \mathrm{g}$ e norfloxacin $10 \mu \mathrm{g}$. S Sensitive, I Intermediate, $R$ Resistant, according to NCCLS (2005)

\section{Selection of antimicrobial extracts from Cerrado plants}

The initial screen revealed that all extracts presented inhibitory effects on at least one of the evaluated bacterial strains. However, the EE from $X$. americana did not show any inhibitory effects on $E$. coli or S. haemolyticus strains (Table 3). The EE and AE from C. brasiliense and EEs from A. crassiflora, S. brasiliensis, and S. lethalis presented antagonism against all Staphylococcus spp. strains. The different phenological stages of C. brasiliense produced leaf extracts showing inhibitory effects against S. aureus and S. haemolyticus (Table 3). Inhibition zone measurements were not associated with tannin content in the extracts tested $(P>0.05$, Pearson correlation).

The EE from A. crassiflora, and EEs and AEs from $S$. brasiliensis and C. brasiliense were selected owing to their inhibitory effects, which produced large inhibition zones. We also considered whether plants acted on one bacterial species or on both, the latter showing a broader spectrum of action. These extracts were sterilized by filtration and concentrations were standardized to $1.58 \mathrm{mg} / \mathrm{mL}$ to compare their effects via diffusion tests in agar.

Table 1 Bacterial identification by 165 rDNA sequencing and classification according to BLAST (NCBI database)

\begin{tabular}{llll}
\hline Isolates & Origen & $\begin{array}{l}\text { Number of analyzed } \\
\text { nucleotides }\end{array}$ & Identification with similarity $>99 \%$ \\
\hline S178 & Cow whit matitis & 551 & Staphylococcus aureus subsp. aureus strain NCTC 8325 \\
S135 & Cow whit matitis & 553 & Staphylococcus haemolyticus strain JCSC1435 \\
S182 & Cow whit matitis & 550 & Staphylococcus haemolyticus strain v JCSC1435 \\
E2 & Calf with diarrhea & 590 & Escherichia coli str. K-12 substr. strain MG1655 \\
E3 & Calf with diarrhea & 574 & Escherichia coli str. K-12 substr. strain MG1655 \\
\hline
\end{tabular}


Table 3 Selection of vegetal extracts according to inhibition zones ( $\mathrm{mm}$ ) produced in Staphylococcus aureus, Escherichia coli, and Staphylococcus haemolyticus after addition of extracts from Cerrado plant leaves in an agar diffusion test

\begin{tabular}{|c|c|c|c|c|c|c|c|c|c|}
\hline \multirow[t]{2}{*}{ Vegetal species } & \multirow[t]{2}{*}{ Extracts } & \multirow{2}{*}{$\begin{array}{l}\text { Tannin } \\
\text { content (\%) }\end{array}$} & \multicolumn{2}{|c|}{ S. haemolyticus } & \multicolumn{2}{|l|}{ S. aureus } & \multicolumn{3}{|c|}{ Escherichia coli } \\
\hline & & & $135 \mathrm{AE}$ & 182 & 178 & ATCC & E2 & E3 & ATCC \\
\hline $\begin{array}{l}\text { Caryocar brasiliense in } \\
\text { flowering }\end{array}$ & Ethanolic & $1.99 \pm 0.12$ & $26.7 \pm 2.5$ & $14.1 \pm 1.9$ & $30.2 \pm 3.4$ & $20.2 \pm 3.3$ & 0.0 & 0.0 & $\overline{19.0 \pm 1.9}$ \\
\hline C.brasiliense in flowering & Aqueous & $1.37 \pm 0.08$ & $23.5 \pm 3.5$ & $14.3 \pm 1.8$ & $21.8 \pm 2.4$ & $19.3 \pm 2.3$ & 0.0 & 0.0 & $14.2 \pm 2.7$ \\
\hline C. brasiliense in fruiting & Aqueous & $1.25 \pm 0.02$ & $24.3 \pm 2.6$ & $14.0 \pm 2,7$ & $21.0 \pm 2.0$ & $23.8 \pm 2.0$ & 0.0 & 0.0 & $16.4 \pm 3.7$ \\
\hline $\begin{array}{l}\text { C. brasiliense flowerless } \\
\text { and fruitless }\end{array}$ & Aqueous & $2.66 \pm 0.22$ & $20.2 \pm 2.0$ & $11.1 \pm 2.6$ & $16.2 \pm 4.1$ & $15.8 \pm 3.1$ & 0.0 & 0.0 & $13.8 \pm 5.0$ \\
\hline Annona crassiflora & Aqueous & $2.59 \pm 1.47$ & $12.8 \pm 2.3$ & 0.0 & $15.9 \pm 2.7$ & $13.1 \pm 4.0$ & 0.0 & $8.0 \pm 3.0$ & 0.0 \\
\hline Annona crassiflora & Ethanolic & $4.20 \pm 2.38$ & $9.3 \pm 2.1$ & $14.5 \pm 1.2$ & $15.9 \pm 3.1$ & $14.6 \pm 3.4$ & 0.0 & $19.8 \pm 4.1$ & $11.1 \pm 3.4$ \\
\hline Piptadenia viridiflora & Aqueous & $0.23 \pm 0.01$ & $16.4 \pm 2.3$ & 0.0 & $19.1 \pm 3.1$ & 0.0 & 0.0 & $11.5 \pm 2.7$ & $29.9 \pm 5.5$ \\
\hline Piptadenia viridiflora & Ethanolic & $1.75 \pm 0.21$ & $9.0 \pm 0.95$ & 0.0 & $13.3 \pm 3.3$ & $17.1 \pm 3.1$ & 0.0 & 0.0 & $27.0 \pm 4.9$ \\
\hline Schinopsis brasiliensis & Aqueous & $0.16 \pm 0.37$ & $16.4 \pm 2.3$ & $18.0 \pm 0.3$ & $24.1 \pm 2.9$ & $20.8 \pm 3.1$ & $9.4 \pm 1.0$ & 0.0 & $22.3 \pm 3.3$ \\
\hline Schinopsis brasiliensis & Ethanolic & $0.72 \pm 0.34$ & $21.7 \pm 3.6$ & $21.2 \pm 4.3$ & $22.5 \pm 2.7$ & $22.8 \pm 2.3$ & 0.0 & $16.2 \pm 3.4$ & $20.6 \pm 5.6$ \\
\hline Serjania lethalis & Ethanolic & $6.37 \pm 0.29$ & $13.2 \pm 2.5$ & $11.0 \pm 2.2$ & $14.5 \pm 3.0$ & $18.5 \pm 4.7$ & 0.0 & $10.0 \pm 3.0$ & $11.7 \pm 4.6$ \\
\hline Casearia sylvestris & Ethanolic & $7.36 \pm 0.54$ & $8.2 \pm 1.3$ & 0.0 & $10.9 \pm 2.0$ & $7.5 \pm 4.3$ & 0.0 & 0.0 & $15.0 \pm 3.8$ \\
\hline Ximenia americana & Ethanolic & $0.29 \pm 0.02$ & 0.0 & 0.0 & 0.0 & $24.2 \pm 4.5$ & 0.0 & 0.0 & 0.0 \\
\hline
\end{tabular}

When evaluating the effects of the five selected extracts on the seven bacterial strains, differences between the type of extract, the plant species, and the strain and species of bacteria were detected $(P<$ 0.001). Consequently, interactions between the type of extract evaluated and the bacterial strain were also significant $(P<0.01$, Table 4). After removal of the tannins, no inhibitory effects were observed for the selected extracts (Table 4).

The AE from S. brasiliensis produced larger inhibition zones against Staphylococcus spp. strains than other extracts. However, considering the $E$. coli strains, the $C$. brasiliense AE produced the largest areas of inhibition among all the extracts (Table $4, P<0.001$ ).
The MICs observed for the EEs from S. brasiliensis and $C$. brasiliense were lower than $A$. crassiflora EE. Both the MIC and MBC of the A. crassiflora EE were $6.24 \mathrm{mg} / \mathrm{mL}$ for all bacterial strains (Table 5).

\section{Reversed-phase HPLC characterization of selected plant extracts}

According to the UV spectra observed, the presence of flavonoids was detected in the region between 261 and $279.3 \mathrm{~nm}$ for the EE from A. crassiflora (Fig. 1), and EE and AE from C. brasiliense (Fig. 2). Tannins were detected in the $\mathrm{EE}$ and $\mathrm{AE}$ of $S$. brasiliensis, with absorbance at 257-263 $\mathrm{nm}$ for the respective retention times (Fig. 3).

Table 4 Average inhibition zones ( $\mathrm{mm}$ ) produced in an agar diffusion test in Staphylococcus aureus, Staphylococcus haemolyticus, and Escherichia coli treated with leaf extracts from Annona Crassiflora, Caryocar brasiliense, and Schinopsis brasiliensis with (TA) or without (WT) tannins $(1.58 \mathrm{mg} / \mathrm{mL})$

\begin{tabular}{|c|c|c|c|c|c|c|c|c|c|c|}
\hline \multirow{2}{*}{$\begin{array}{l}\text { Bacteria } \\
\text { Strains }\end{array}$} & \multicolumn{2}{|c|}{ A. crassiflora Ethanolic- } & \multicolumn{2}{|c|}{ C. brasiliense Ethanolic } & \multicolumn{2}{|c|}{ C. brasiliense Aqueous } & \multicolumn{2}{|c|}{ S. brasiliensis Ethanolic } & \multicolumn{2}{|c|}{ S. brasiliensis Aqueous } \\
\hline & $\overline{\mathrm{TA}}$ & WT & $\overline{\mathrm{TA}}$ & WT & $\overline{\mathrm{TA}}$ & WT & $\overline{\mathrm{TA}}$ & WT & $\overline{\mathrm{TA}}$ & WT \\
\hline S135 & $7.3 \pm 0,67 \mathrm{Dd}$ & 0 & $8.1 \pm 0,11 \mathrm{Ce}$ & 0 & $6.1 \pm 0,08 \mathrm{Ed}$ & 0 & $9.4 \pm 0,27 \mathrm{Bb}$ & 0 & $10.0 \pm 0,18 \mathrm{AC}$ & 0 \\
\hline S182 & $6.9 \pm 0,38 \mathrm{Ce}$ & 0 & $6.5 \pm 0,20 \mathrm{Dg}$ & 0 & $6.1 \pm 0,11 \mathrm{Ed}$ & 0 & $9.3 \pm 0,22 \mathrm{Bb}$ & 0 & $10.8 \pm 0,33 \mathrm{AC}$ & 0 \\
\hline S178 & $8.6 \pm 0,47 \mathrm{DC}$ & 0 & $8.4 \pm 0,04 \mathrm{Dd}$ & 0 & $6.1 \pm 0,11 \mathrm{Ed}$ & 0 & $9.1 \pm 0,29 \mathrm{Bb}$ & 0 & $9.8 \pm 0,11 \mathrm{AC}$ & 0 \\
\hline ATCC 25923 & $7.0 \pm 0,06 \mathrm{Ee}$ & 0 & $7.3 \pm 0,18 \mathrm{Df}$ & 0 & $9.4 \pm 0,4 \mathrm{Cc}$ & 0 & $10.2 \pm 0,22 \mathrm{Ba}$ & 0 & $15.1 \pm 0,18 \mathrm{Aa}$ & 0 \\
\hline E2 & $9.8 \pm 0,31 \mathrm{Ba}$ & 0 & $8.9 \pm 0,18 \mathrm{Dc}$ & 0 & $14.1 \pm 0,18 \mathrm{Ab}$ & 0 & $6.2 \pm 0,07 \mathrm{Ec}$ & 0 & $9.3 \pm 0,22 \mathrm{Cc}$ & 0 \\
\hline E3 & $9.5 \pm 0,76 \mathrm{Cb}$ & 0 & $9.4 \pm 0,27 \mathrm{Db}$ & 0 & $14.8 \pm 0,27 \mathrm{Aa}$ & 0 & $6.1 \pm 0,15 c$ & 0 & $12.4 \pm 1,44 \mathrm{Bb}$ & 0 \\
\hline ATCC 25922 & $10.1 \pm 0,53 \mathrm{Da}$ & 0 & $11.3 \pm 0,2 \mathrm{Ca}$ & 0 & $14.5 \pm 0,44 \mathrm{Aa}$ & 0 & $8.5 \pm 0,29 \mathrm{EC}$ & 0 & $11.9 \pm 0,22 \mathrm{Bb}$ & 0 \\
\hline
\end{tabular}

Lowercase letters in lines indicate significant difference between bacteria strains and uppercase letters in columns indicate significant difference between plant extracts as determined by Scoott-Knott'test with a 5\% significance

${ }^{a}$ S. haemolyticus (S135 and S182); S. aureus (S178 and ATCC 25923) and E. coli (E2,E3 and ATCC25922) 
Table 5 Minimum inhibitory concentration (MIC) and minimum bacterial concentration (MBC) of leaf extracts from Annona Crassiflora, Caryocar brasiliense, and Schinopsis brasiliensis tested on Escherichia coli and Staphylococcus spp. from cattle

\begin{tabular}{|c|c|c|c|c|c|c|c|c|c|c|}
\hline \multirow{3}{*}{$\begin{array}{l}\text { Bacteria } \\
\text { strains }^{a}\end{array}$} & \multirow{2}{*}{\multicolumn{2}{|c|}{$\frac{\text { Annona crassiflora }}{\text { Ethanolic mg/mL }}$}} & \multicolumn{4}{|c|}{ Caryocar brasiliense } & \multicolumn{4}{|c|}{ Schinopsis brasiliensis } \\
\hline & & & \multicolumn{2}{|c|}{ Ethanolic mg/mL } & \multicolumn{2}{|c|}{ Aqueous mg/mL } & \multicolumn{2}{|c|}{ Ethanolic mg/mL } & \multicolumn{2}{|c|}{ Aqueous mg/mL } \\
\hline & $\overline{M I C}$ & MBC & $\overline{\mathrm{MIC}}$ & MBC & $\overline{M I C}$ & $\mathrm{MBC}$ & $\overline{M I C}$ & $M B C$ & $\overline{\mathrm{MIC}}$ & MBC \\
\hline \multicolumn{11}{|c|}{ Staphylococcus spp. } \\
\hline S135 & 6.24 & 6.24 & 0.27 & $>40.0$ & 0.71 & 0.71 & 0.17 & 0.34 & 0.42 & 0.42 \\
\hline S182 & 6.24 & 6.24 & 0.27 & $>40.0$ & 0.71 & 0.71 & 0.17 & 0.68 & 0.42 & 0.84 \\
\hline S178 & 6.24 & 6.24 & 0.27 & $>40.0$ & 0.71 & $>40.0$ & 0.17 & 0.34 & 0.42 & 0.42 \\
\hline ATCC 25923 & 6.24 & 6.24 & 0.27 & $>40.0$ & 0.71 & 0.71 & 0.17 & 0.68 & 0.42 & 0.84 \\
\hline \multicolumn{11}{|l|}{ Escherichia coli } \\
\hline E2 & 6.24 & 6.24 & 0.27 & $>40.0$ & 0.71 & $>40.0$ & 0.17 & 0.34 & 0.10 & 0.42 \\
\hline E3 & 6.24 & 6.24 & 0.27 & $>40.0$ & 0.71 & 0.71 & 0.17 & 0.34 & 0.42 & 0.42 \\
\hline ATCC 25922 & 6.24 & 6.24 & 0.27 & 30.0 & 0.71 & $>40.0$ & 0.17 & 0.34 & 0.42 & 0.42 \\
\hline
\end{tabular}

${ }^{a}$ S. haemolyticus (S135 and S182); S. aureus (S178 and ATCC 25923) and E. coli (E2, E3 and ATCC25922)

\section{Discussion}

In this study, six plants showed inhibitory effect against the three bacterial species evaluated, indicating the importance of bioprospecting studies on Cerrado vegetation. We observed intra- and inter-species differences in the bacterial susceptibility to plant extracts, which should be clarified in future investigations.

The differences in inhibition zones produced by the five selected extracts could be associated with their biochemical compositions, polarity, and solubility in Muller-Hinton agar. Additionally the interactions and the differences of extract constituents of the extracts could explain their spectra of action against Gram-positive or Gram-negative bacteria.

In agar diffusion test, the best inhibitory action against the Gram-negative E. coli strains was promoted by $C$. brasiliense AE which contained flavonoids. However, the AE from S. brasiliensis, containing tannins, produced larger inhibition zones in the Gram-positive Staphylococcus spp. strains than did other extracts. We suggested intra-specific variations in bacterial response to the extracts, considering the different effects of these

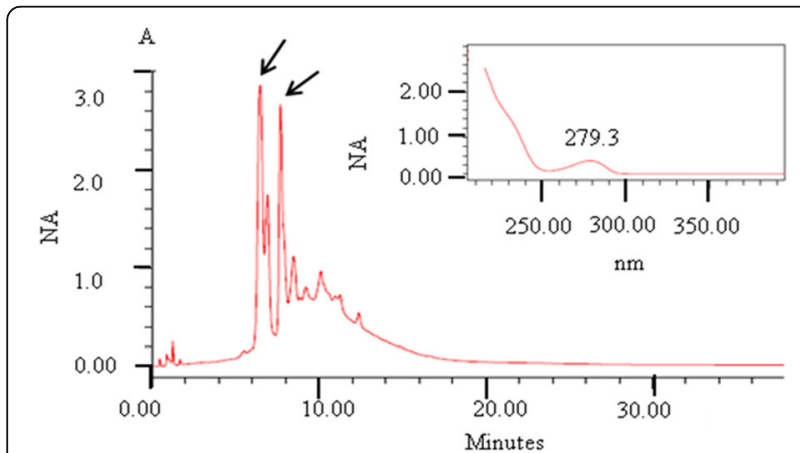

Fig. 1 HPLC chromatographic profile, retention times (RT), and UV (279.3 $\mathrm{nn})$ spectrum characteristics of flavonoids, in panels inside the image, in the ethanolic extract from Annona crassiflora (first RT $=6.484 \mathrm{~min}$ ). extracts against human clinical strains (E. coli ATCC 25922 and S. aureus ATCC 25923) and respective bovine isolates. The different hosts could lead to the selection of external or internal variations in these bacteria, which could influence their susceptibly to these extracts. However, this would need to be elucidated in future research.

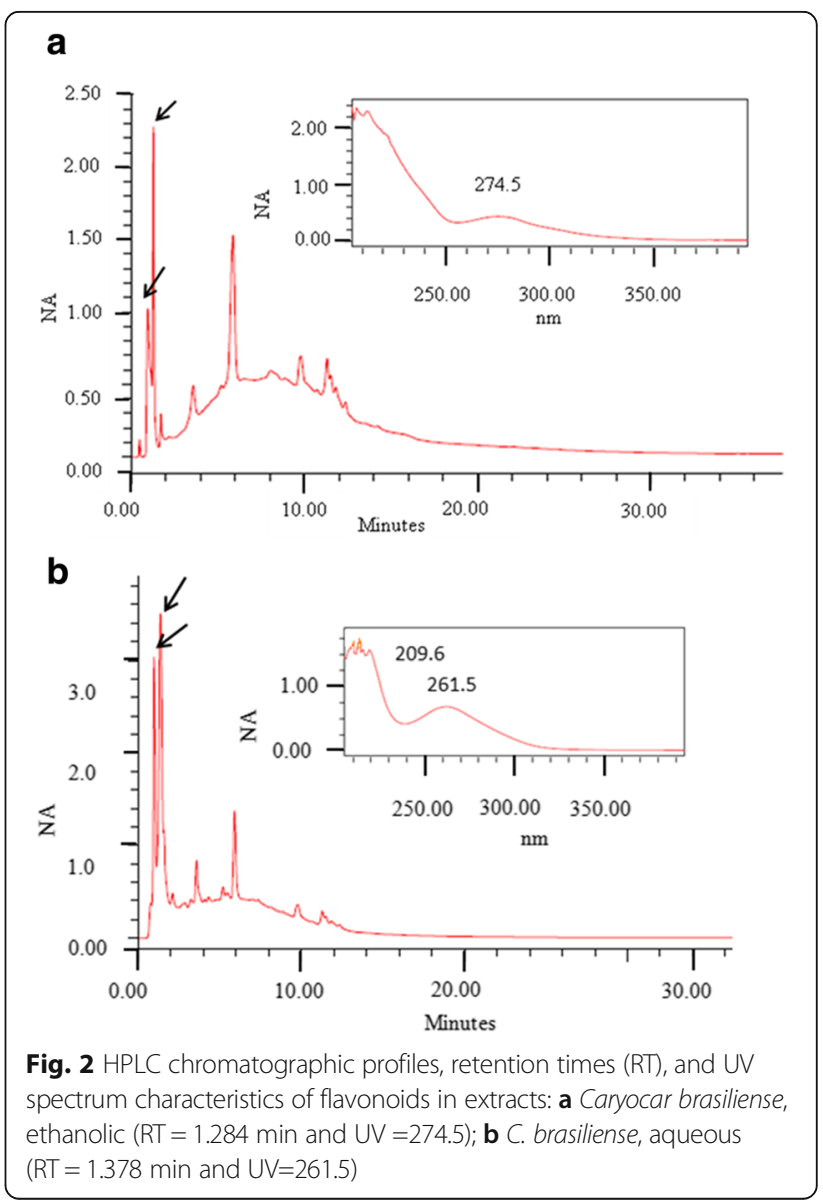



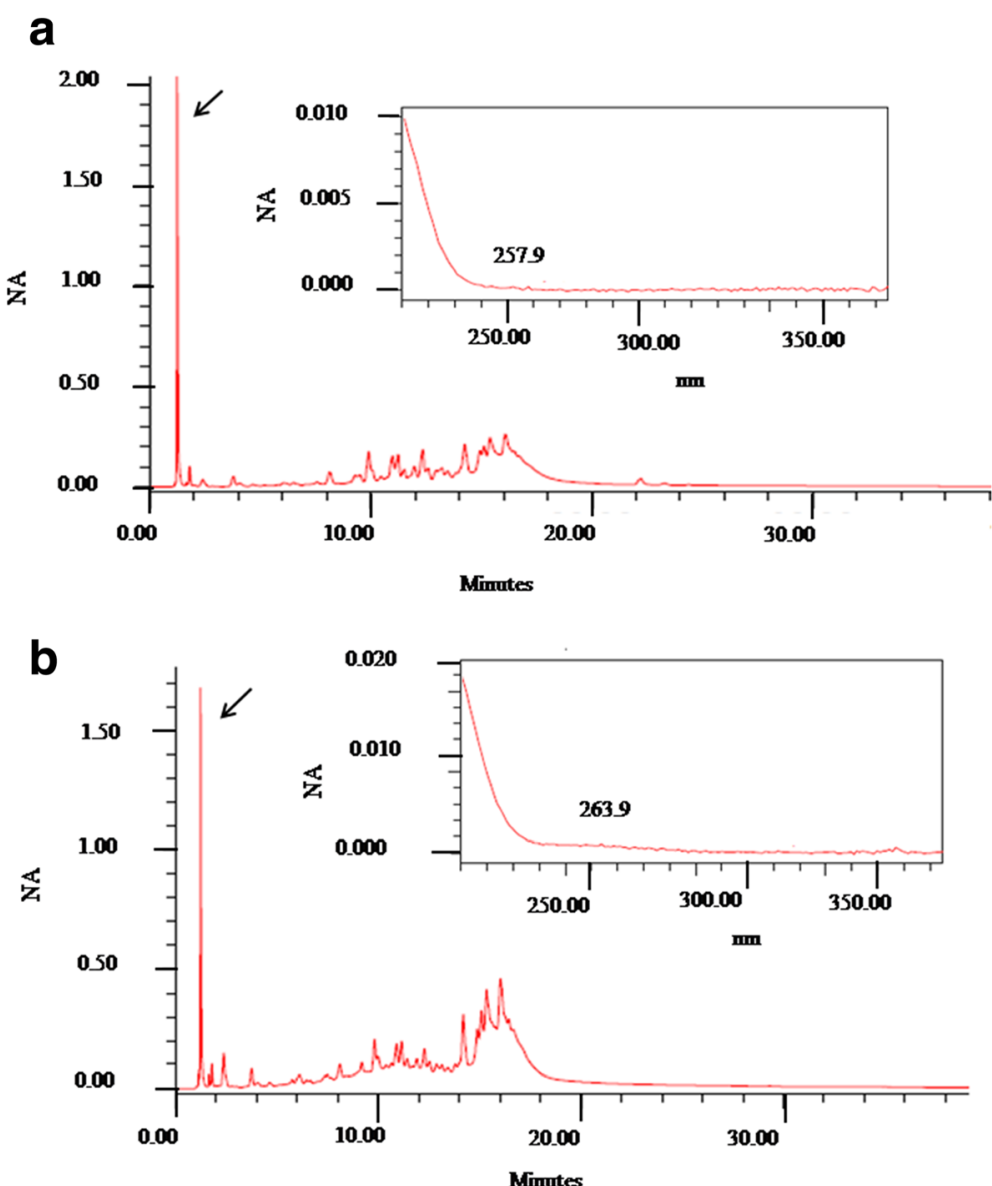

Fig. 3 HPLC chromatographic profiles, retention times (RT), and UV spectrum characteristics of tannins in extracts: a Schinopsis brasiliensis, ethanolic (RT = $1.053 \mathrm{~min}$ and $\mathrm{UV}=257.9) ; \mathbf{b}$ Schinopsis brasiliensis, aqueous (RT =1.054 $\mathrm{min}$ and $\mathrm{UV}=263.9$ )

A specific mechanism of action against Staphylococcus spp. or E. coli could be explained by differences in cell wall constitutions of Gram-negative and Gram-positive bacteria [27]. Specific constituents in C. brasiliense extracts such as saponins and flavonoids could be more toxic to walls with greater lipid contents, as was observed in E. coli $[28,29]$.

We detected that a lower number of the effective extracts against the Gram-negative bacteria. In another antibacterial screening of plants from the Cerrado revealed that the stem bark extracts from Qualea grandiflora Mart (Vochysiaceae), Virola surinamensis (Rol.) Warb (Myristicaceae), and Hancornia speciosa Gome (Apocynaceae) significantly inhibited $S$. aureus but were not effective against $E$. coli [13].

The results obtained in this research corroborate with those of the study by Lima et al. [30] that evaluated the in vitro antimicrobial activity of EEs (1:1) from leaves, fruits, and seeds of A. crassiflora against Staphylococcus spp. The authors showed that these extracts significantly inhibited bacterial growth with a mean inhibition zone of 10 to $12 \mathrm{~mm}$. Silva et al. [31] also reported inhibition zones of 10 to $14 \mathrm{~mm}$ when analyzing the effects of $A$. crassiflora leaf extracts against multi-resistant human $S$. aureus.

Considering antibacterial effects of $C$ brasiliensis, unlike the leaf extracts in our study, bark extracts used at $500 \mathrm{mg} / \mathrm{mL}$ showed no inhibition when tested against the reference strains of $S$. aureus and $E$. coli [32]. These results indicate the leaves, which are more available, as sustainable source of the antibacterial metabolites of this plant.

Analyzing the MICs observed in this research, the EEs and AEs from $S$. brasiliensis and C. brasiliense were more effective against all bacterial strains than A. crassiflora extract. However MBC values were different among the bacterial strains, thus showing intra-specific variations. The EE of C. brasileiense showed bacteriostatic effect while other extracts were bactericides.

Although of few scientific studies describe antagonistic effects of plant extracts against Gram-negative bacteria, we detected that the extracts from $C$. brasiliense and $S$. brailiensis had lower MICs against E. coli strains than other studies. Paula-Junior et al. [28] reported that the 
hydroethanolic extract from $C$. brasiliense leaves exhibited MIC values of $4 \mathrm{mg} / \mathrm{mL}$ against $E$. coli and $S$. aureus, and Amaral et al. [33] described higher MICs for $C$. brasiliense EE against E. coli ATCC 25922 (MIC of $11.25 \mathrm{mg} / \mathrm{mL})$ and S. aureus ATCC $6538(22.5 \mathrm{mg} / \mathrm{mL})$.

In other study, low MICs have also been reported for S. brasiliensis, E. coli ATCC 9723, and multi-resistant S. aureus isolates, with values varying from 0.025 to $0.100 \mathrm{mg} / \mathrm{mL}$, depending on the fraction of extracts [14].

In this study, the EE of A. crassiflora showed MIC and $\mathrm{MBC}$ of $6.4 \mathrm{mg} / \mathrm{mL}$ for all bacteria evaluated, indicating this extract is safe and can ensure complete inhibition or death of these microorganisms. Silva et al. [31] evaluated the effects of leaf extract of this plant against oxacillinresistant human $S$. aureus and ATCC 6538, and observed higher MICs $(25 \mathrm{mg} / \mathrm{mL})$ for both strains. Furthermore, the authors identified alkaloids and flavonoids as the active compounds.

Considering HPLC analysis, the EE of A. crassiflora and both extracts from $C$. brasiliense presented flavonoids while the tannins were main components detected for S. brasiliensis extracts. However, these analyses cannot reveal the concentration or chemical structure of these metabolites. The characterization of these extracts by other methods, such as gas chromatography after derivation, could reveal reveal the contents of their specific antibacterial components.

In this study, inhibitory effects were no observed after tannin removal from the selected extracts, indicating that this metabolite represented the main antibacterial agent in these extracts. Future studies should elucidate the mechanism of action of these extracts, and whether such effects can be linked to a group of substances promoting bacterial inhibition.

The antimicrobial role of these plant metabolites has not yet been clearly elucidated. However, there is a consensus of multiple mechanisms of action on bacterial cells. The tannins can interact with the cytoplasmic membrane, inhibiting its function and thereby compromising cellular integrity [11]. These compounds could also inhibit nucleic acid and enzymes synthesis, modify the cellular metabolism via membrane interaction, and complex with metal ions to decrease its availability for the microorganisms [34]. The antibacterial activity of flavonoids has been attributed to inhibition of DNA gyrase, inhibition of cytoplasmic membrane function, and energy metabolism. These compounds represent a novel source that can be utilized to develop pharmacologically acceptable antimicrobial agents [35].

Other studies have characterized the main metabolites of the plants selected in this research. Phytochemical tests of C. brasiliense identified condensed tannins, hydrolyzed tannins, flavonoids, terpenoids, and saponins, which could contribute synergistically with antibacterial effects $[28,29]$. In the $A$. crassiflora extracts, alkaloids, acetogenins, flavonoids, and phenolic compounds have previously been detected [36].

We used the disk-diffusion assay for the antimicrobial screening of plant extracts which showed simplicity and low cost as reported by Balouiri et al. [37]. However, bactericidal and bacteriostatic effects were not distinguished and special attention should be given to the standardization of bacterial inocula and microbial procedures to reduce the variability of measures of the inhibition zones. The selected leaf extracts of native plants from the Cerrado showed inhibitory effects against three bacterial species related to mastitis or colibacillosis in cattle; both diseases that have caused significant economic loss in cattle production in several continents. The E. coli strains used were resistant to tetracycline and the S178 S. aureus isolate was multi-resistant. These results could be explained by bovine herds infected with $S$. aureus and E. coli being frequently treated with antimicrobials to control mastitis or colibacillosis [2, 3].

The selected extracts from native plants of the Cerrado could prove to be alternative agents for the control of colibacillosis, mastitis, and other diseases associated with these bacteria, after toxicity studies and in vivo tests are performed. The specific metabolites present in these extract could be essential to control resistant or multi-resistant bacterial strains.

\section{Conclusion}

In this research, Staphylococcus spp. and E. coli were sensitive to leaf extracts of native plants from the Cerrado. Inter- and intra-specific bacterial variations were detected with regards to extract susceptibility. Notably, the A. crassiflora EE and S. brasiliensis extracts show potent bactericidal activity. After removal of the tannins, no antimicrobial effects were observed, indicating these metabolites are the main active antibacterial components.

\section{Abbreviation}

AE: Aqueous extract; EE: Ethanolic extract; MBC: Minimum bactericidal concentrations; MIC: Minimum inhibitory concentrations

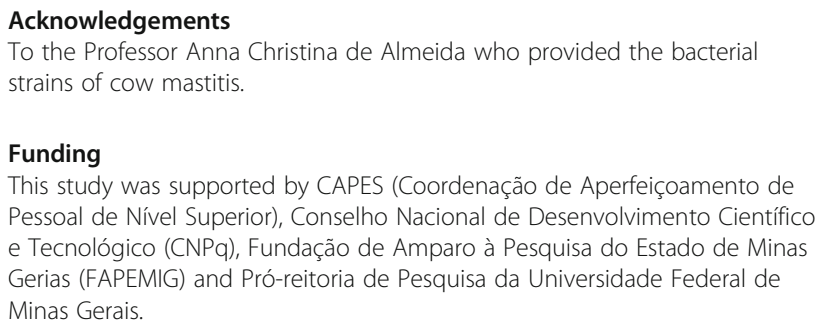

Availability of data and materials

The datasets used and/or analyzed during the current study and voucher number of the plants are available from the corresponding author on reasonable request. 


\section{Authors' contributions}

ERD conceived, designed and coordinated the study. ICOR, EGAM, FMC FMCA, MRS participated in data collection, analyses and drafting the manuscript. ERD and ICOR finalized and submitted the manuscript for publication. All the authors revised and approved the final manuscript.

\section{Ethics approval}

The bacterial isolates were collected in previous experiments submitted and approved by the Ethics Committee on Animal Experiments of the UFMG (protocol n ${ }^{\circ}$ 39/2009 and 145/2013), regulated by the National Council for Control of Animal Experimentation of Brazil.

\section{Consent for publication}

Not applicable.

\section{Competing interests}

The authors of this manuscript have no financial or personal relationships with other people or organizations that could inappropriately influence or bias the content of the paper

\section{Publisher's Note}

Springer Nature remains neutral with regard to jurisdictional claims in published maps and institutional affiliations.

\section{Author details}

'Instituto de Ciências Agrárias, Universidade Federal de Minas Gerais, Avenida Universitária, 1000, Bairro Universitário, Montes Claros, Minas Gerais CEP 39401-790, Brazil. ²Escola de Medicina Veterinária, Universidade Federal de Minas Gerais, Av. Antonio Carlos, 6627 Pampulha, Belo Horizonte, MG CEP 31270-901, Brazil. ${ }^{3}$ Instituto de Ciências Agrárias, Universidade Federal de Minas Gerais, Av Universitária 1000, Bairro Universitario, Montes Claros, MG 39400-006, Brazil.

Received: 6 January 2017 Accepted: 16 January 2018

Published online: 30 January 2018

\section{References}

1. Salvadori MR, Valadares GF, Leite DS, Blanco J, Yano T. Virulence factors of Escherichia coli isolated from calves with diarrhea in Brazil. Brazil J Microbiol. 2003;34:230-5.

2. Duse A, Waller KP, Emanuelson U, Unnerstad HE, Persson Y, Bengtsson B. Risk factors for antimicrobial resistance in fecal Escherichia coli from preweaned dairy calves. J Dairy Sci. 2015:98:500-16.

3. Su X, Howell AB, D'Souza DH. Antibacterial effects of plant-derived extracts on methicillin-resistant Staphylococcus aureus. Foodborne Pathog Dis. 2012;9:573-8.

4. Saidi R, Khelef D, Kaidi R. Bovine mastitis: prevalence of bacterial pathogens and evaluation of early screening test. Afr J Microbio Res. 2013;7:777-82.

5. Toyang NJ, Wanyama J, Nuwanyakpa M, Django S. Ethnoveterinary medicine: a practical approach to the treatment of cattle diseases in sub-Saharan 2 ed Africa Roosendaal. Netherlands: Agromisa Foundation and CTA; 2007

6. Sampimon OC, Lam TJGM, Mevius DJ, Schukken YH, Zadoks RN. Antimicrobial susceptibility of coagulase-negative staphylococci isolated from bovine milk samples. Vet Microbiol. 2011;150:173-9.

7. Samoilova Z, Smirnova G, Muzyka N, Oktyabrskya O. Medicinal plant extracts variously modulate susceptibility of Escherichia coli to different antibiotics. Microbiol Res. 2014:169:307-13.

8. Ammer MR, Zaman S, Khalid M, Bilal M, Erum S, Huang D Che S Optimization of antibacterial activity of Eucalyptus tereticornis leaf extracts against Escherichia coli through response surface methodology. J Radiation Res Appl Sc. 2016:9:376-85.

9. Pereira AV, Silva VA, Freitas AFR, Pereira MSV, Trevisan LFA, Costa MRM Extratos vegetais: atividade antimicrobiana e genética sobre plasmídios de resistência a antibióticos em microrganismos. Rev Biol Farmac. 2010:4:60-5.

10. Mordmuang A, Voravuthikunchai SP. Rhodomyrtus tomentosa (Aiton) Hassk leaf extract: an alternative approach for the treatment of staphylococcal bovine mastitis. Res Vet Sci. 2015;102:242-6.

11. Mello CP, Santos SC. Taninos 4 ed In: Farmacognosia: da planta ao medicamento Porto Alegre: Editora Universitária/UFRGS/Ed da UFSC; 2002.
12. Silva Júnior MCS. 100 Árvores do Cerrado: guia de campo. Brasília: Rede de Sementes do Cerrado; 2005. p. 278.

13. Costa ES, Hiruma-Lima CA, Lima EO, Sucupira GC, Bertolin AO, Lolis SF, Andrade FDP, Vilegas W, Souza-Brito ARM. Antimicrobial activity of some medicinal plants of the cerrado, Brazil. Phytother Res. 2008;22:705-7.

14. Saraiva AM, Saraiva CL, Cordeiro RP, Soares RR, Xavier HS, Caetano N. Atividade antimicrobiana e sinérgica das frações das folhas de Schinopsis brasiliensis Engl frente a clones multirresistentes de Staphylococcus aureus. Rev Bras Plants Medic. 2013;15:99-207.

15. Chapaval L, Moon DH, Gomes JE, Duarte FR, Tsai SM. An alternative method for Staphylococcus aureus DNA isolation. Arq Bras Med Vet Zootec. 2008;60:299-306.

16. Lane DJ. 16S/23S rRNA sequencing. In: Stackebrandt E, Goodfellow M, editors. Nucleic acid techniques in bacterial systematics. Chichester: Wiley; 1991. p. $115-75$

17. Sanger F, Coulson AR. A rapid method for determining sequences in DNA by primed synthesis with DNA polymerase. J Mol Biol. 1975;94:441-8.

18. Reysenbach AL, Longnecker K, Kirshtein J. Novel bacterial and archaeal lineages from an in situ growth chamber deployed at a mid-atlantic ridge hydrothermal vent. Appl Environ Microbiol. 2000;66:3798-806.

19. NCCLS. Performance Standards for Antimicrobial Susceptibility Testing. Fifteenth Informational Supplement [Online] CLSI/NCCLS document M100S15 [ISBN 1-56238-556-9] Clinical and Laboratory Standards Institute, 940 West Valley Road, Suite 1400, Wayne, Pennsylvania 19087-1898 USA. 2005. Available: http://www.anvisagovbr/servicosaude/ manuais/clsi/clsi_OPASM100S15.pdf [Accessed 10 May 2015].

20. Alvares CA, Stape JL, Sentelhas PC, JLM G, Sparovek G. Köppen's climate classification map for Brazil. Meteorol Z. 2014:22:711-28.

21. Matos FJA. Introdução a Fitoquímica. UFC: Fortaleza; 2009. p. 150.

22. Nyman U, Joshi P, Madsen LB, Pinstrup M, Rajasekharan S, George V, Pushpangadan P. Ethnomedical information and in vitro screening for angiotensin-converting enzyme inhibition of plants utilized as traditional medicines in Gujarat, Rajasthan and Kerala (India). J Ethnopharmacol. 1998:60:247-63.

23. Hiermann A, Kartnig TH, Azzam S. Ein Beitrag zur quantitativen Bestimmung der Procyanidine in Crataegus. Sci Pharm. 1986;54:331-7.

24. CLSI. Performance Standards for Antimicrobial Susceptibility Testing. Wayne: Twenty-First Informational Supplement CLSI document M100-S21Clinical and Laboratory Standards Institute; 2011.

25. NCCLS. Methods for Dilution Antimicrobial Susceptibility Tests for Bacteria That Grow Aerobically. Approved Standard-Sixth Edition [Online] NCCLS document M7-A6 [ISBN 1-56238-486-4] NCCLS, 940 West Valley Road, Suite 1400, Wayne, Pennsylvania 19087-1898 USA, 2003. Available: (http:// www.anvisagovbr/servicosaude/manuais/clsi/clsi_OPASM2-A8.pdf) [Accessed 10 May 2015].

26. Klancnik A, Piskernik S, Jersek B, Mozina SS. Evaluation of diffusion and dilution methods to determine the antibacterial activity of plant extracts. J Microbiol Methods. 2010;81:121-6.

27. Malanovic N, Lohner K. Gram-positive bacterial cell envelopes: the impact on the activity of antimicrobial peptides. Biochim Biophys Acta. 2016;1858:936-46.

28. Paula-Júnior W, Rocha FH, Donatti L, CMT F-p, Weffort-santos AM. Leishmanicidal, antibacterial, and antioxidant activities of Caryocar brasiliense Cambess leaves hydroEE. Rev Bras Farmacogn. 2006;16:625-30

29. Miranda-Vilela AL, Resck IS, Grisolia CK. Antigenotoxic activity and antioxidant properties of organic and aqueous extracts of pequi fruit (Caryocar brasiliense Camb) pulp. Genet Mol Biol. 2008;31:956-63.

30. Lima MRF, Ximenes CPA, Luna JS, Sant'ana AEG. The antibiotic activity of some Brazilian medicinal plants. Braz Med Plants. 2006;16:300-6.

31. Silva JJ, Cerdeira CD, Chavasco JM, Cintra ABP, Silva CBP, Mendonça AN Ishikawa T, Boriollo MFG, Chavasco JK. In vitro screening antibacterial activity of Bedens pilosa Linné and Annona crassiflora Mart against oxacillin resistant Staphylococcus aureus (ORSA) from the aerial environment at the dental clinic. Rev Inst Med Trop Sao Paulo. 2014;56:333-40.

32. Pinho L, Souza PNS, Macedo Sobrinho E, Almeida AC, Martins ER. Atividade antimicrobiana de extratos hidroalcoolicos das folhas de alecrim-pimenta, aroeira, barbatimão, erva baleeira e do farelo da casca de pequi. Cienc Rural. 2012:42:326-31.

33. Amaral LFB, Moriel P, Foglio MA, Mazzola PG. Caryocar brasiliense supercritical $\mathrm{CO} 2$ extract possesses antimicrobial and antioxidant 
properties useful for personal care products. BMC Complement Altern Med. 2014;73:14-73.

34. Scalbert A. Antimicrobial properties of tannins. Phytochemistry. 1991;30: 3875-83.

35. Cushnie TPT, Lamb AJ. Antimicrobial activity of flavonoids. Int J Antimicrobial Agents. 2005;26:343-56.

36. Roesler R, Malta LG, Carrasco LC, Holanda RB, Souza CAS, Pastore GM. Atividade antioxidante de frutas do Cerrado. Cienc Tecnol Aliment. 2007;27:53-60.

37. Balouiri M, Sadik M, Ibnsouda SK. Methods for in vitro evaluating antimicrobial activity: a review. J Pharmt Anal. 2016;6:71-9.

Submit your next manuscript to BioMed Central and we will help you at every step:

- We accept pre-submission inquiries

- Our selector tool helps you to find the most relevant journal

- We provide round the clock customer support

- Convenient online submission

- Thorough peer review

- Inclusion in PubMed and all major indexing services

- Maximum visibility for your research

Submit your manuscript at www.biomedcentral.com/submit
Biomed Central 